University of Wollongong

Research Online

Faculty of Social Sciences - Papers (Archive) Faculty of Arts, Social Sciences \& Humanities

2013

Preparation for teaching gifted students: An updated investigation into university offerings in New South Wales

Kylie Fraser-Seeto

University of Wollongong, ktfs995@uowmail.edu.au

Steven J. Howard

University of Wollongong, stevenh@uow.edu.au

Stuart Woodcock

University of Wollongong, stuart.woodcock@mq.edu.au

Follow this and additional works at: https://ro.uow.edu.au/sspapers

Part of the Education Commons, and the Social and Behavioral Sciences Commons

Research Online is the open access institutional repository for the University of Wollongong. For further information contact the UOW Library: research-pubs@uow.edu.au 


\title{
Preparation for teaching gifted students: An updated investigation into university offerings in New South Wales
}

\author{
Abstract \\ Gifted and talented students are a diverse and often overlooked group of students. Research suggests \\ that this may be at least partly related to limited gifted and talented education training at the preservice \\ level. In fact, within an Australian context, preservice training in gifted and talented education in Australia \\ has consistently been found to be insufficient. Given that the last study of Australian preservice gifted and \\ talented education offerings was conducted in 2005 , however, the current study sought to investigate \\ whether these provisions had substantially changed in the eight years since that study. Further, this study \\ sought to provide a more detailed view of offerings (e.g., undergraduate vs. post-graduate, elective vs. \\ compulsory, credit point values) by University. Results revealed marginal increases in subject offerings at \\ the undergraduate level, which continue to fall short of Senate recommendations, and a shift toward \\ longer-term training at the post-graduate level. The implications of these trends for teacher preparedness \\ are discussed.

\section{Keywords} \\ students, updated, investigation, university, into, preparation, teaching, gifted, wales, south, offerings

\section{Disciplines} \\ Education | Social and Behavioral Sciences

\section{Publication Details} \\ Fraser-Seeto, K., Howard, S. J. \& Woodcock, S. (2013). Preparation for teaching gifted students: An \\ updated investigation into university offerings in New South Wales. Australasian Journal of Gifted \\ Education, 22 (2), 45-51.
}


Preparation for teaching gifted students: An updated investigation into university offerings in New South Wales

Kylie Fraser-Seeto ${ }^{\mathrm{a}}$, Steven J. Howard ${ }^{\mathrm{a}}$ and Stuart Woodcock ${ }^{\mathrm{a}}$

${ }^{\mathrm{a}}$ School of Education, University of Wollongong, New South Wales, 2522, Australia

Corresponding author: Kylie Fraser-Seeto, School of Education, University of Wollongong, New South Wales, 2522, Australia; Email: ktfs995@uowmail.edu.au; Phone +61 416213 638. 


\begin{abstract}
Gifted and talented students are a diverse and often overlooked group of students. Research suggests that this may be at least partly related to limited gifted and talented education training at the preservice level. In fact, within an Australian context, preservice training in gifted and talented education in Australia has consistently been found to be insufficient. Given that the last study of Australian preservice gifted and talented education offerings was conducted in 2005, however, the current study sought to investigate whether these provisions had substantially changed in the eight years since that study. Further, this study sought to provide a more detailed view of offerings (e.g., undergraduate vs. post-graduate, elective vs. compulsory, credit point values) by University. Results revealed marginal increases in subject offerings at the undergraduate level, which continue to fall short of Senate recommendations, and a shift toward longer-term training at the post-graduate level. The implications of these trends for teacher preparedness are discussed.
\end{abstract}

Keywords: gifted, talented, preservice, professional development, university, training 


\section{Literature Review}

Gifted and talented students are a diverse and often overlooked group of students. The term 'gifted and talented' is often used to refer to students with extraordinary potential (gifted) and/or performance (talented) in one or more domains of human ability (e.g., intellectual, creative, social, psychomotor; Gagnè, 1985). Importantly, these students tend to have cognitive, affective and social needs that differ from those of other students in mainstream classrooms (Shaywitz, Holahan, \& Freudenheim, 2001; Tomlinson, 2005). For instance, research illustrates that these students are often cognitively and affectively more advanced than their same-aged peers (Maker \& Schriever, 2010; Plunkett \& Kronborg, 2011; Shaywitz, Holahan, \& Freudenheim, 2001; Tomlinson, 2005), and thus require differentiated learning experiences to realise their potential. Whilst provisions do exist within Australia for dedicated gifted and talented programming (e.g., Opportunity Classes, Selective High Schools), the majority of Australia's gifted and talented students are found within mainstream classrooms (Bragget \& Moltzen, 2000; Taylor \& Milton, 2006). As a consequence, all teachers must be prepared (possess the requisite knowledge, skills and experience) to provide appropriate educational experiences for these students.

Whilst gifted and talented students clearly have a range of special educational needs, in mainstream contexts these 'specialised' supports are often eschewed due to perceptions that these students are already academically advantaged and are certain to thrive on their own (Gallagher, 2003; Lassig, 2009; Van Tassel-Baska, 1997). This (mis)perception is in stark contrast to evidence that gifted and talented students are unlikely to succeed on their own (Plunkett, 2002) and that educators play an influential role in the development, learning and achievement of these students (Lassig, 2003; McCoach, 2007; Plunkett, 2002). This role of educators is further highlighted by Gagnè’s (2003, 2010) Differentiated Model of Giftedness and Talent (DMGT), which acknowledges the development of gifted into talents as facilitated 
(or hindered) by both interpersonal and environmental catalysts. Specifically, Gagnè acknowledges the influential role teachers and educational experiences have on whether a gifted student's exceptional potential is translated into talent (exceptional performance).

Mounting evidence continues to highlight the importance of quality pre-service teacher training for developing the knowledge, tools, support and training required to appropriately cater for the academic, affective and social needs of gifted and talented students (for a review, see Rowley, 2012). For instance, Kagan (1992) found that undertaking specialised training that challenges teachers' beliefs can alter their misconceptions of gifted and talented students. This is especially important given research identifying teachers' beliefs and attitudes toward gifted and talented education as one of the most significant factors influencing their classroom practices, pedagogy and the educational outcomes of gifted and talented students in mainstream classrooms (Gallagher, 2007; Lewis \& Milton, 2005).

Despite these positive impacts, research continues to suggest that this form of training remains insufficient (Commonwealth of Australia, 1988, 2001; Rowley, 2012; Taylor \& Milton, 2006). Within this context, gifted and talented students have been identified as one of the most educationally disadvantaged groups in Australian Schools (Braggett \& Moltzen, 2000; Parliament of the Commonwealth, 2001; Rowley, 2012). In support of this assertion, it has been estimated that up to 75 percent of gifted students in Australia underachieve in school and as many as 40 percent leave school before the end of Year 12 (Parliament of the Commonwealth of Australia, 2001). Contributing to this disadvantage is the fact that teachers are often under-prepared (i.e., lacking the requisite knowledge, skills and self-efficacy) for identifying and meeting the needs of gifted and talented students within mainstream classrooms (Hudson et al., 2010; Taylor \& Milton, 2006; Troxclair, 2013). Moreover, research as recent as 2006 showed that few improvements had been made in the area of 
teacher training in gifted and talented education (Kronborg \& Moltzen, 1999; Taylor \& Milton, 2006).

\section{Policy and Change in Australian Gifted and Talented Education}

The idea that we need to better provide for our gifted and talented students is not new. In fact, the 1988 Report of the Select Committee on the Education of Gifted and Talented Children (Parliament of the Commonwealth of Australia, 1988) placed a direct focus on teacher education. For instance, one recommendation of the report was that:

...preservice training courses include sufficient information about gifted children to make student teachers aware of the needs of those children and the special identification techniques and teaching strategies which the student teachers will have to use with the gifted on graduation (Parliament of the Commonwealth of Australia, 1988, par.7.27).

Although this represents a formal acknowledgement of the essential nature of preservice training, this report failed to gain governmental support and none of the recommendations were formally implemented (Kronborg, 2002; Vialle \& Rogers, 2009).

Subsequently, in 2001, the Australian Senate Inquiry on the Education of Gifted and Talented Children (Parliament of the Commonwealth of Australia, 2001) solicited submissions from experts, teachers and researchers in gifted education, resulting in a reiteration and expansion of those earlier recommendations. In particular, the Inquiry found that the state of gifted education was an ongoing concern throughout Australia and that education systems were not meeting the needs of these students. As a result, it was suggested that our gifted and talented students were frequently experiencing boredom, frustration, psychological distress and underachievement (DeBuhr, 2011; Parliament of the Commonwealth of Australia, 2001). The Inquiry also highlighted research indicating that the negative attitudes and misinformed beliefs of teachers toward gifted students were adversely 
affecting the achievement levels of these students (Parliament of the Commonwealth of Australia, 2001). In fact, the Inquiry found that many teachers had an inadequate understanding of gifted and talented students, which resulted in insufficient expertise, confidence and resources to cater for their needs.

As means to rectify this, the committee made 20 recommendations for strengthening gifted and talented education in Australia, with a notable emphasis on teacher training and professional development. In fact, three of the recommendations pertained to preservice teacher training in gifted and talented education. That is, the Inquiry recognised the need for improved training for teachers in gifted and talented education, as well as better curriculum support to ensure that teachers are able to appropriately differentiate the curriculum and effectively meet the diverse needs of gifted and talented children. Of note, the majority of the 20 recommendations were almost identical to the nine made in the 1998 Inquiry, which highlights the lack of action taken to implement and support the original recommendations.

\section{The Status of Preservice Teacher Training in Australia}

Despite these recommendations, the availability of preservice training in gifted and talented education continues to be limited. For instance, a 1999 investigation into tertiary courses in gifted education across Australasian universities (Kronborg \& Moltzen, 1999) identified few undergraduate subjects in gifted and talented education on offer at Australian universities. Instead, these provisions were more widespread at the Doctorate and Graduate Certificate level. A quantitative follow-up study (Taylor \& Milton, 2006) indicated that of the 35 Primary teacher-training degrees on offer in Australia, none included compulsory subjects, and four included elective subjects, dedicated to gifted and talented education. Further, only eight universities across three states offered compulsory special education subjects with an explicit gifted and talented component. An additional 11 elective subjects in gifted and talented education across five states were offered as part of a Bachelor of Primary Education 
degree. It was only at the postgraduate level that a range of gifted and talented education subjects and degrees were regularly offered (in all but four states). Both studies highlight the continued lack of provision for preservice teaching training in gifted and talented education, despite the Senate Inquiry Recommendation that "state and territory education authorities should require, as a condition of employment, that newly graduated teachers have at least a semester unit on the special needs of gifted children in their degrees” (Parliament of the Commonwealth of Australia, 2001, p.96)

\section{The Current Study}

Given that the last study of Australian preservice gifted and talented education offerings was conducted in 2005, however, the current study sought to investigate whether these provisions had substantially changed in the eight years since that study. Further, this study sought to provide a more detailed view of these offerings (e.g., undergraduate vs. postgraduate, elective vs. compulsory, credit point values) by University, albeit in a more restricted geographical area. Specifically, we sought to investigate current provisions of New South Wales (NSW) universities for gifted and talented education. Results of this study were then compared to a similar study conducted by Taylor and Milton (2006) to ascertain what changes, if any, had occurred since 2005. This study therefore aims to contribute to an overall picture of provisions in NSW to prepare teachers to meet the needs of gifted and talented students in mainstream classrooms.

\section{Methods}

\section{Data Sources and Collection}

To investigate current university provisions for preservice teachers in gifted and talented education, courses (i.e., degree/qualification received) and subjects on offer at all NSW universities $(N=14)$ were examined. Data on university offerings were initially collected using university websites and handbooks. For each university, data consisted of the quantity 
(i.e., credit points, subjects, courses) and type (i.e., compulsory, elective) of undergraduate and post-graduate offerings in gifted and talented education. This data was subsequently member-checked via telephone calls and emails to each university to ensure accuracy of the extracted information. A total of eight universities confirmed their data via telephone contact, another three via email confirmation and a further three pointed to their University Handbook for current information regarding their current courses and subjects.

Initial categorisation of the data mirrored the methods of Taylor and Milton (2006), however nuances in university offerings required that additional distinctions be made. For instance, in line with Taylor and Milton (2006), initial characterisations of the data considered all undergraduate education courses that offered a teaching qualification upon completion (e.g., Bachelor of Early Childhood, Bachelor of Primary Education and Bachelor of Education - Secondary). However, there was a lack of clarity regarding which courses Taylor and Milton (2006) considered as distinct. For the purposes of the current study, embedded honours programs were not considered as separate courses, given the extensive overlap of their degree requirements (except in the final year of study). However, where Primary Education courses were offered as a Dean's Scholar Program, and were assigned their own course number, these were treated as a distinct Education course. Further, in recognition of the presence of partial and integrated (with special education) gifted and talented subjects, the number credit points, as well as the type of subject (i.e., compulsory vs. elective, dedicated vs. integrated, undergraduate vs. postgraduate) was determined separately for each university. Postgraduate gifted and talented courses and subjects offered at each university were further categorised as a graduate certificate, graduate diploma, Master of Education with a gifted and talented component or a Doctoral qualification with a gifted and talented component.

\section{Results}


Current undergraduate offerings in gifted and talented education are presented in Table

1. Results indicated that NSW universities offered a total of 104 undergraduate courses in

Education in 2013. This figure is inclusive of all early childhood ( $n=11 ; 10.58 \%)$, primary ( $n$ $=27 ; 25.96 \%)$, secondary $(n=51 ; 49.04 \%)$ and other $(n=15 ; 14.42 \%)$ education courses (e.g., double degrees in education with no teaching qualification upon graduation, Bachelor of Arts courses majoring in Education). Within these courses, a total of three compulsory gifted and talented subjects were offered, although at one university this subject involved only a half-semester of study (3 credit points). These core subjects were offered by only two of the 14 universities (14.29\%). A further three universities offered four elective subjects in gifted and talented education, with an additional elective subject available at a university that also offered two mandatory subjects. Each of these elective units involved a minimum of one full semester dedicated to gifted and talented education. In sum, five (35.7\%) NSW universities offered at least one dedicated gifted and talented education subject, with only two universities (14.3\%) making the subject mandatory.

Table 1 NSW Universities: Undergraduate Gifted Education Offerings in 2013

\begin{tabular}{lccccccc}
\hline University & $\begin{array}{c}\text { Edu. } \\
\text { Courses }\end{array}$ & $\begin{array}{c}\text { Primary } \\
\text { Courses }\end{array}$ & \multicolumn{2}{c}{$\begin{array}{c}\text { G\&T Subjects } \\
\text { (Core) }\end{array}$} & $\begin{array}{c}\text { G\&T Subjects } \\
\text { (Elect) }\end{array}$ & $\begin{array}{c}\text { No. Special Ed } \\
\text { Subjects } \\
\text { (Core + Elect) }\end{array}$ \\
\hline CSU & 10 & 2 & 0 & Credit Pts. & No. & Credit Pts. & \\
Macquarie & 12 & 4 & 0 & - & 2 & 8,8 & 1 \\
UNSW & 5 & 0 & 0 & - & 0 & - & 1 \\
Sydney & 6 & 1 & 0 & - & 1 & 6 & 1 \\
ACU & 9 & 2 & 0 & - & 0 & - & 3 \\
UWS & 5 & 3 & 0 & - & 0 & - & 3 \\
ANU & 0 & 0 & 0 & - & 0 & - & 1 \\
UOW & 10 & 2 & 1 & 3 & 0 & - & 0 \\
SCU & 10 & 2 & 0 & - & 1 & 12 & 1 \\
UNE & 12 & 2 & 2 & 6,6 & 1 & 6 & 0 \\
Newcastle & 8 & 2 & 0 & - & 0 & - & 1 \\
UTS & 4 & 2 & 0 & - & 0 & - & 0 \\
Canberra & 8 & 2 & 0 & - & 0 & - & 0 \\
ND & 5 & 3 & 0 & - & 0 & - & 1 \\
\hline TOTAL & $\mathbf{1 0 4}$ & $\mathbf{2 7}$ & $\mathbf{3}$ & $\mathbf{9}$ & $\mathbf{5}$ & $\mathbf{3 2}$ & $\mathbf{1 3}$ \\
\hline TM(2006) & - & 10 & 0 & - & 4 & - & 10 \\
\hline
\end{tabular}

Note. G\&T = gifted and talented. Elect = elective. Special Ed = special education/inclusive. TM2006 = Taylor and Milton (2006). 
Many universities also incorporated special education or inclusivity subjects, although it is unclear whether any of these incorporated a gifted and talented component. Although university handbooks gave a broad overview of subject content, many failed to explicitly indicate the time allocated to gifted and talented education within these special/inclusive education subjects. Nevertheless, 13 special/inclusive education subjects (core plus elective) were offered at nine (64.29\%) of the 14 universities. Combining this with the previous data, a total of 10 NSW universities (71.43\%) provided at least one subject in gifted and talented education or special/inclusive education (14.29\% offered both). Importantly, $21.4 \%$ of NSW universities failed to offer any subjects relating to gifted an talented education as a mandatory, elective or embedded (as part of inclusive education) subject.

A comparison of these findings to those of Taylor and Milton (2006) highlighted a number of changes in NSW universities' gifted and talented education offerings. Compared to no compulsory gifted and talented education subjects being offered by NSW universities in 2005, three compulsory subjects were offered in 2013. The number of gifted and talented elective/subjects on offer also increased from four in 2005 to five in 2013. A comparison of special/inclusive education subjects indicated an increase from 10 special/inclusive education subjects in 2005 to 13 subjects in 2013.

Current post-graduate offerings in gifted and talented education are presented in Table 2. Results indicated a total of 202 postgraduate Education courses across NSW universities. Of these offerings, three were postgraduate certificates in gifted and talented education (a 50\% reduction from the six offered in 2005) and one was a postgraduate diploma in gifted and talented education (a decrease of two-thirds from the three offered in 2005). A further seven postgraduate courses offered a Master of Education with a gifted and talented speciality in 2013 (an increase of 75.0\% over the four courses available in 2005). Results for postgraduate Doctoral courses with a gifted and talented specialty also showed an increase from three 
courses in 2005 to four courses in 2013 (an increase of 33.3\%). Results thus suggest a shift toward offering gifted and talented education courses at the Masters/Doctoral level of study.

Table 2

NSW Universities: Postgraduate gifted education offerings in 2013

\begin{tabular}{lccccc}
\hline University & Edu Courses & $\begin{array}{c}\text { PG } \\
\text { G\&T Cert. }\end{array}$ & $\begin{array}{c}\text { PG } \\
\text { G\&T Dipl. }\end{array}$ & $\begin{array}{c}\text { M.Ed. } \\
\text { (G\&T spec.) }\end{array}$ & $\begin{array}{c}\text { Ph.D. } \\
\text { (G\&T spec.) }\end{array}$ \\
\hline CSU & 20 & 0 & 0 & 0 & 0 \\
Macquarie & 33 & 0 & 0 & 0 & 0 \\
UNSW & 9 & 0 & 0 & 1 & 1 \\
Sydney & 40 & 1 & 1 & 1 & 1 \\
ACU & 28 & 0 & 0 & 0 & 0 \\
UWS & 8 & 0 & 0 & 0 & 0 \\
ANU & 0 & 0 & 0 & 0 & 0 \\
UOW & 28 & 1 & 0 & 2 & 2 \\
SCU & 4 & 0 & 0 & 1 & 1 \\
UNE & 14 & 1 & 0 & 1 & 1 \\
Newcastle & 7 & 0 & 0 & 1 & 1 \\
UTS & 3 & 0 & 0 & 0 & 0 \\
Canberra & 5 & 0 & 0 & 0 & 0 \\
Notre Dame & 3 & 0 & 0 & $\mathbf{7}$ & $\mathbf{4}$ \\
\hline TOTAL & $\mathbf{2 0 2}$ & $\mathbf{3}$ & $\mathbf{1}$ & 3 \\
\hline TM(2006) & - & 6 & 3 &
\end{tabular}

\section{Discussion}

This study sought to investigate the current state of gifted and talented education training at the preservice level across NSW universities. In doing so, data were tabulated to compare with, update and expand upon a comparable study (Taylor \& Milton, 2006) to ascertain what, if any, changes had occurred over the past eight years. This study thus sought to contribute to the wider body of research that explores teacher professional development in gifted and talented education by investigating the preservice opportunities that contribute to preparing educators to meet the needs of gifted and talented students within a mainstream classroom.

When considering the vast number of education courses offered across NSW universities $(N=306)$ in 2013, the possibilities for providing educators with access to gifted and talented education subjects appear to be substantial. Despite university courses covering a wide range of topics across Early Childhood, Primary and Secondary education, however, our data 
revealed that provisions of gifted and talented subjects at core (mandatory) and elective level continues to be marginal within the NSW context. For instance, at the undergraduate level only two (14.29\%) of 14 NSW universities offered a gifted and talented education subject as a mandatory/core component of an Education course. Adding elective gifted and talented education subjects, only five (35.71\%) NSW universities offered gifted and talented subjects to their undergraduate students.

A comparison of these results with those of Taylor and Milton (2006) revealed that very little has changed in the area of preservice gifted and talented education provisions in the past eight years. Whilst there has been a slight positive shift in the number of core/compulsory gifted and talented education subjects offered (from none to three), it is noted that these occurred at only two of 14 NSW universities. Further, there was only a slight increase in elective gifted and talented education subjects (from four to five). In another continuing trend, gifted and talented education subjects continue to be offered predominantly as an elective component of NSW Education courses. Given the optional nature of elective subjects, this requires an existing interest in this area for uptake by education students. This is problematic in that research suggests participation in gifted and talented education training programs can positively impact an educator's perceptions and ability to provide appropriate, differentiated learning experiences for these students (Bangel, Moon, \& Capobianco, 2010; DeBuhr, 2011; Lassig, 2009; Plunkett, 2000; Tomlinson, 2005). As such, the largely elective nature of preservice gifted and talented education training likely limits the number of future teachers receiving these benefits.

Importantly, these trends are in direct opposition to the recommendations made by the 2001 Senate Inquiry (Parliament of the Commonwealth of Australia, 2001). Specifically, the inquiry concluded that a minimum of a one-semester subject dedicated to gifted and talented education should be a feature of all preservice teacher training courses. This, however, is 
currently occurring at only one of the 14 universities in NSW. In contrast, special/inclusive education continues to be well represented within preservice teacher training (with nine out of 14 NSW universities including special/inclusive education subjects as part of their education courses). This commitment to special/inclusive education contrasts the limited provisions for gifted and talented education training, which appears to be less widely acknowledged as a necessary means to provide for the needs of the entire range of students in the mainstream classroom (Lassig, 2009).

Contrasting our findings with respect to undergraduate offerings, and consistent with prior research, postgraduate education courses continue to be a more consistent source of gifted and talented education provisions (Parliament of the Commonwealth of Australia, 2001; Taylor \& Milton, 2006). That is, although the overall number of gifted and talented offerings at the postgraduate level has remained static since 2005 (Taylor \& Milton, 2005), a number of certificate and diploma courses appear now to have shifted towards more researchbased courses (i.e., Master's, Doctorate). This suggests a shift towards gifted and talented education as an increasingly specialist area (e.g., reserved for further study) and requiring greater commitment (e.g., in length of study; Braggett, 1993; DeBuhr, 2011). Moreover, given that engagement with this form of postgraduate study is inherently elective in nature, access to this training requires individual interest and desire in this area. The impacts of this shift, both in uptake of study and outcomes for gifted and talented students, remain unknown and warrant further investigation.

It is noted that education courses and subject content therein are open to change from year to year. This shift can be additive in nature, as illustrated by one university that has a planned shift from a half-semester to full-semester gifted and talented education subject in 2015. These changes may also be subtractive in nature, as illustrated by another university that no longer offers the online gifted and talented elective subject they offered in 2005. As 
such, whilst these results give a snapshot of offerings available in 2013, this does not preclude change in future years. Unfortunately, however, minimal evidence of intended changes was encountered in the process of data collection.

\section{Conclusion}

This study extends the findings of Taylor and Milton (2006) by providing a more indepth and updated examination of provisions for gifted and talented education within NSW universities. In taking a closer look at preservice teacher training, results have shown that gifted and talented education offerings at the university level continue to be insufficient relative to minimum standards outlined by previous senate inquiries (Parliament of the Commonwealth of Australia, 2001). As a consequence, graduating teachers may lack the requisite knowledge, skills and self-efficacy to identify and cater for the needs of these students. Although there is mounting evidence of the benefits of teacher training in gifted and talented education, (Kagan 1992; Lassig, 2009; Parliament of the Commonwealth of Australia, 2001; Rowley, 2012), the degree and long-term stability of these benefits are not well known. Future research is thus required to investigate the immediate and long-term impacts of preservice gifted and talented education training in order to explore the effectiveness of gifted and talented teacher training at this stage of professional development and beyond. Nevertheless, our findings provide a vital starting point from which to begin mapping comprehensive and cohesive provisions for gifted and talented education at the preservice level. 


\section{References}

Bangel, N. J., Moon, S. M., \& Capobianco, B. M. (2010). Preservice teachers’ perceptions and experiences in a gifted education training model. Gifted Child Quarterly, 54(3), 209-221.

Braggett, E. J. (1993). Recent historical forces on gifted education in Australia. Australasian Journal of Gifted Education, 2(1), 16-20.

Braggett, E. J., \& Moltzen, R. I. (2000). Programs and practices for identifying and nurturing giftedness and talent in Australian and New Zealand. In K. A. Heller, F. J. Monks, R. J. Sternberg, \& R. F. Subotnik (Eds.), International Handbook of Giftedness and Talent (pp.779-798). Oxford, UK: Elsevier.

DeBuhr, D. (2011). Submission to the Parliament of Victoria Education and Training Committee: Inquiry into the education of gifted and talented students. Retrieved from http://www.parliament.vic.gov.au/images/stories/committees/etc/Past_Inquiries/EGTS_In quiry/Submissions/46_Deborah_DeBuh.pdf

Gagnè, F. (1985). Giftedness and talent: Reexamining a re-examination of the definitions. Gifted Child Quarterly, 29. 103-112.

Gagnè, F. (2003). Transforming gifts into talents: The DMGT as a developmental theory. In N. Colangelo \& G. A. Davis (Eds.), Handbook of gifted education ( $3^{\text {rd }}$ ed.) (pp. 60-74). Boston, MA: Allyn and Bacon.

Gagnè, F. (2010). Motivation within the DMGT 2.0 framework. High Ability Studies, 1(2), 81-99.

Gallagher, S. (2003). Issues and challenges in the education of gifted students. In N. Colangelo \& G. A. Davis (Eds.), Handbook of gifted Education ( $3^{\text {rd }}$ ed.) (pp.11-23). Boston, MA: Allyn and Bacon.

Gallagher, S. (2007). Reflections from the deep end: Primary school teachers’ 
experiences of gifted education. Australasian Journal of Gifted Education, 16(1), 20-29.

Hudson, P., Hudson, S., Lewis, K., \& Watters, J. J. (2010). Embedding gifted education in preservice teacher education: A collaborative school-university approach. Australasian Journal of Gifted Education, 19(2), 5-15.

Kagan, D. M. (1992). Professional growth among pre-service and beginning teachers. Review of Educational Research, 62. 129-169.

Kronborg, L. (2002). Foreword. In W. Vialle \& J. Geake (Eds.), The gifted enigma (pp. vi-xxi). Melbourne, VIC: Hawker Brownlow Education.

Kronborg, L., \& Moltzen, R. (1999). AAEGT report on gifted courses: Tertiary courses in gifted education across Australia, New Zealand and Asia. Australasian Journal of Gifted Education. 18(1), 77-79.

Lassig, C. (2003). Gifted and talented education reforms: Effects on teachers’ attitudes. In B. Bartlett, F. Bryer, \& D. Roebuck (Eds.), Proceedings $1^{\text {st }}$ Annual International Conference on Cognition, Language, and Special Education Research (pp.141-152). Surfer's Paradise, QLD: School of Cognition, Language \& Special Education, Griffith University. Retrieved from http://eprints.qut.edu.au/14299/1/14299.pdf

Lassig, C. (2009). Teachers' attitudes towards the gifted: The importance of professional development and school culture. Australasian Journal of Gifted Education, 18(2), 32-42.

Lewis, E., \& Milton, M. (2005). Attitudes of teachers before and after professional development. Australasian Journal of Gifted Education. 14(1), 5-14.

McCoach, D. B. (2007). What predicts teachers' attitudes toward the gifted? Gifted Child Quarterly, 51(3), 246-255.

Maker, J., \& Schiever, S. W. (2011). Curriculum development strategies for gifted 
learners ( $3^{\text {rd }}$ ed.). Austin, TX: Pro-Ed.

Parliament of the Commonwealth of Australia. (1988). Report of the Select Committee on the Education of the Gifted and Talented Children. Canberra, ACT: Australian Government Publishing Services.

Parliament of the Commonwealth of Australia. (2001). The education of gifted children. Retrieved from http://www.aph.gov.au.ezproxy.uow.edu.au/Parliamentary_Business/Committees/Senate _Committees?url=eet_ctte/completed_inquiries/1999-02/gifted/report/contents.htm

Plunkett, M. (2000). Educating teachers to meet the needs of the gifted: An option or a necessity? TalentEd, 18(1), 9-16.

Plunkett, M. (2002). Impacting on teacher attitudes toward gifted students. In W. Vialle \& J. Geake (Eds.), The gifted enigma (pp. 240-249). Melbourne, VIC: Hawker Brownlow.

Plunkett, M., \& Kronborg, L. (2011). Learning to be a teacher of the gifted: The importance of examining opinions and challenging misconceptions. Gifted and Talented International, 26(1), 31-46.

Rowley, J. (2012). Professional development needs of teachers to identify and cater for gifted students. Australasian Journal of Gifted Education, 21(2), 75-80.

Shaywitz, S. E., Holahan, J. M., \& Freudenheim, D. A. (2001). Heterogenity within the gifted: Higher IQ boys exhibit behaviours resembling boys with learning disabilities. Gifted Child Quarterly, 45(1), 16-23.

Taylor, T., \& Milton, M. (2006). Preparation for teaching gifted students: An investigation into university courses in Australia. Australian Journal of Gifted Education, 15(1), 25-31.

Tomlinson, C. A. (2005). Travelling the road to differentiation in staff development. 
Journal of Staff Development, 26(4), 8-12.

Troxclair, D. A. (2013). Preservice teacher attitudes towards giftedness. Roeper Review, 35(1), 58-64.

Van Tassel-Baska, J. (1997). Excellence as a standard for all education. Roeper Review, 20(1), 68-72.

Vialle, W., \& Rogers, K. B. (2009). Educating the gifted learner. Terrigal, NSW:

David Barlow Publishing. 